\title{
The Impact of Decentralized Fiscal Funds on Primary Schooling in Kenya
}

\author{
Sagire Lucas \\ School of Economics, University of Nairobi, Nairobi, Kenya
}

Email address:

sagirelucas@gmail.com

To cite this article:

Sagire Lucas. The Impact of Decentralized Fiscal Funds on Primary Schooling in Kenya. International Journal of Elementary Education . Vol. 6, No. 3, 2017, pp. 24-31. doi: 10.11648/j.ijeedu.20170603.12

Received: June 27, 2017; Accepted: July 17, 2017; Published: August 11, 2017

\begin{abstract}
Improved standards of living for citizens is what any government strives to achieve. In doing this, governments use different methods. Governments improve welfare of its citizens through provision of public goods or utilities from which citizens derive utility. Many governments have set up various fiscal funds to that end. This study investigated the effect of fiscal funds on social welfare in the Kenyan context. In particular, the study determined the effect of Constituency Development Fund (CDF) on demand for primary schooling, a quasi-public good. A time series from 1970 to 2015 was used. Annual enrollment in class one in public schools was used as the dependent variable while the explanatory variables were; MCg (government expenditure per pupil), CDF which was dummy, parent literacy and Pupil-Teacher ratio. MCg and parent literacy have significant effect on primary schooling.
\end{abstract}

Keywords: Fiscal Funds, CDF, Public Good, Social Welfare

\section{Introduction}

Fiscal decentralization consists primarily of devolving revenue sources and expenditure functions to lower tiers of government [11]. It brings the government closer to people thus expected to boost public sector efficiency, accountability and transparency in service delivery and policy-making. During the 1990s, fiscal decentralization programmes were the most widespread trends for development in most of the developing countries. However, many of these initiatives have made limited progress towards achieving their stated goals. Because of the uneven performance, there has been contested debate on whether they are desirable or not with some supporting the idea and others oppose. The proponents assert that decentralization improves governance and local public service provision in several ways [22]. Fiscal decentralization was entrenched in the Kenya constitution (2010). This implies that more finances have been decentralized to the county government from the time the new constitution was adopted. Currently, the cash transfers are called "devolved funds" in Kenya [15]. The government of Kenya has been emphasizing on economic growth since independence because it is seen as a key ingredient to alleviate poverty [21]. Poverty reduction is a sign of economic growth, which translates to improved welfare in the country. This is evident in all core public documents; [14] and [13], which emphasize rapid and sustained economic growth as a way to alleviate poverty. In its effort to achieve this, the government has for years embarked on fiscal decentralization strategies with a bias towards fiscal/devolved funds.

Some of the government's decentralization efforts over the years include District Development Program of 1966, the special Rural program (1969/1970), District Development Planning (1971) and District Focus for Rural Development (1988-1989). Despite the fact that all these programs were meant to develop the rural economies and the country by extension, they suffered same challenge of lack of funding by the national government [24]. This implies that the programs have not done much in improving welfare. It is from this point that the government came up with other decentralized funds such as Road Maintenance Levy Fund (1993), Secondary Schools Education Bursary Fund (1993), and Rural Electrification Programme (1998), Local Authority Transfer Fund (1999), Water Services Trust Fund (2002) Constituency Development Fund (2007). All these have been operational from when they were started to the present times although some like LATF were abolished in the spirit of the 
Kenya Constitution (2010). According to records from the National Treasury, there are other short-term programmes, which have also led to the flow of funds from the national government to rural areas. These include; The Youth Empowerment Programme, commonly known as Kazi Kwa Vijana Fund, Economic Stimulus Programme and the recently launched 6 billion Uwezo Fund. The ESP was introduced in the fiscal year 2009/2010 with the objective of initiating various infrastructure projects under health, education, markets, industrial centers and fish enterprise development as well as recruiting nurses and teachers. Records from the implementing agencies concerned reveal that these funds have been flowing to the rural areas at an increasing rate, for example CDF allocations increased from Ksh. 7.26 billion (2005/2006 financial year) to Ksh. 10.038 (2006/2007 financial year).

[28] and [30] reveal that the country has recorded wide fluctuations in economic growth. These fiscal funds are expected to improve the living standards in the country. Despite this, majority of the rural communities still languish in poverty [12]. [18], [28] and [29] indicate that poverty in some rural areas has been increasing despite the increase in resource allocation to these areas. As at 2009, $90 \%$ of the people in Mandera were living below the poverty line compared to $60 \%$ in 2006 [18]. On average, approximately $50 \%$ of the Kenyan population cannot meet the minimum levels of basic needs and thus live in poverty [10]. One of the major arguments for decentralized funds is to address the problem of inequality in the country. However, available estimates of the Ginni coefficients for Kenya show that inequality has been increasing in the country. The country's Gini coefficient based on households' income was estimated at 0.419 in 1997 compared to 0.459 in 2005/2006 [18]. Although the population living in poverty has declined, the number of those living below the poverty line is estimated to have increased from 13.4 million in 1997 to about 16.6 million in 2006 [17]. The slight increase in Ginni coefficient imply increased inequality, which therefore means that the devolved funds have done little in poverty alleviation hence have not improved welfare in Kenya.

Poverty, which is one of the key socio-economic indicators, remains relatively high and there are wide regional differences. The national average headcount poverty was in 2003 estimated at $53.3 \%$ and ranged from Kajiado's $16 \%$ to Turkana's $94.5 \%$ [10]. The equalization fund is expected to overcome the challenge of uneven development. Indeed ensuring prosperity across all areas will require that counties or areas within counties with relatively high poverty rates such as Turkana (94.5\%), Mandera (88.3\%) and Wajir $(86.5 \%)$ be provided with commensurately larger fiscal resources. The fund is to provide basic services such as water, roads, health facilities and electricity to marginalized areas to the extent necessary to bring the quality of those services in those areas to the level generally enjoyed by the rest of the people. The availability and accessibility of these facilities to citizens is a sure indicator of economic development, which is critical in improving people's welfare. [9] assert that to care about growth and poverty issues, one should be concerned about efficiency-supplying services up to the point at which, at the margin, the welfare benefit to society matches its cost. However, sometimes the market-price mechanism may fail to do this and at this point public sector intervention in favor of fiscal decentralization is key.

The devolved fiscal funds are to help achieve various objectives such as bringing public services closer to people, improving service delivery and enhancing decision-making at the grass root with the overall objective to boost economic growth, which translates to economic development leading to improved welfare [11]. A close examination of economic surveys show that majority of people in rural communities still languish in poverty [17]. This indicates a wanting state of the welfare of most Kenyans in general despite the recent increment in the allocations of the funds. Records from National Treasury indicate that in addition to the existing fiscal funds, there are other short-term programmes such as Uwezo fund, which have led to flow of funds to rural areas. Implementing agencies reveal that these funds have been flowing at an increasing rate for example CDF allocations increased from KSH. 7.26 billion in 2005/2006 fiscal year to KSH.10.038 billion in 2006/2007 fiscal year. Despite these, the country still records huge numbers of people still languishing in poverty and poor education. This study measures the effect of fiscal funds on welfare of Kenyans and discusses the policy implications of the effect.

\section{Literature Review}

General welfare refers to all economic and non-economic goods and services that provide utilities or satisfaction to individuals living in a community [2]. According to the Paretian welfare criteria, welfare is said to increase (or decrease) if at least one person is made better off (or worse off) with no change in the positions of others. This means that any change which harms no one and which makes some people better off is an improvement. Thus, there is need for any government to have a proper formula for distributing resources equally.

[4] state that fiscal finance constitutes a very critical component of fiscal decentralization. The paper as such, relies on the fiscal decentralization theory. Fiscal decentralization transfers resources to lower levels of government thus enhancing improved welfare since the preferences of citizens vary across jurisdictions. This is done by matching government output to local tastes and increasing efficiency both in providing government services and in generating revenue [23].

Some studies have indicated a significant impact of decentralized funds to economic development in Kenya thus improving welfare. [5] notes that through CDF, many schools have been built and equipped. This has boosted the government's policy of providing free primary school education. In the health sector, many hospitals, dispensaries, maternity wings and clinics have been built in record time. This has been to decongest larger district level hospitals and 
increase the accessibility of healthcare. In addition, the CDF has helped crime prone areas to construct police posts, which the central government has been quick to bring into operation to reaffirm its commitment to public safety. However, a closer look at the reports on implementation of the CDF in recent years reveals a mismatch between the local nature of capital expenditure decisions and financing for the operations and maintenance of such projects with local benefits.

Other studies have indicated that although the government has increasingly allocated substantial resources to decentralized funds since 1990 s, it has not significantly improved the national response to poverty, inequitable resource distribution and generally the welfare of Kenyans. Nonetheless, some success in terms of capital development projects, roads and hospitals have been build and rehabilitated using the CDF and LAT funds. The number of people living below the poverty line has increased with increase in allocations [25]. Further, there was a $30 \%$ increase of people living below the poverty line despite these funds being in place [25]. According to [18], Malindi had $65 \%$ of the people living below poverty line compared to $61 \%$ in 2006 , while $83 \%$ of people in Galole were living below the poverty line in 2009 compared to $46 \%$ in 2006 . In Mandera, $90 \%$ of people were living below the poverty line in 2009 compared to $60 \%$ in 2006. This dismal performance of the funds may be attributed to persistent challenges such as lack of effective participation of local communities in selecting, prioritizing and implementing development projects, poor public finance management at national and sub-national levels and lack of institutional monitoring and evaluation mechanisms among others. The study further observed that weaknesses such as limited public oversight on existing resources and mismanagement of the funds at the sub-national levels have not translated into desired outcomes against poverty and inequality.

[31] and [20] have argued that fiscal decentralization is harmful to societies. The negative perception is fuelled by the numerous challenges associated with fiscal decentralization such as increasing deficits, corruption, and increased influence of interest groups and greater inter-regional inequalities, which might slow down the pace of economic growth that ultimately hinders welfare improvement in societies [27]. Due to weak accounting systems in developing countries, the delivery of resources and public services is considered to be at a greater risk of corruption and opportunistic behavior at lower levels of government [33]. [26] observe that if the resource sharing formula is not properly thought of, fiscal decentralization might worsen the problem of regional inequalities. Fiscal decentralization may be harmful to the growth of the economy, and hence on social welfare especially the growing ones because corruption among politicians at sub-national levels may be worse than corruption at the national level thus poor public management systems at the local level might result to more wastage [35].

Many studies on the relationship between fiscal decentralization and economic growth have been carried out with an attempt to quantify the role of government expenditures on economic growth. However, none of these studies has been concerned with the impact of fiscal funds on peoples' welfare. As a result, this study uses the literature that explains the relationship between fiscal decentralization and economic growth which is a necessary requirement for improved welfare so that it can be possible to find the link between decentralized funds and society's welfare in the Kenyan context.

[32] explored the relationship between economic growth and fiscal decentralization in Central and Eastern Europe. They used sub-national expenditures as a percentage of total expenditure, tax revenues as a percentage of total national revenues, grants and transfers to sub-national governments as explanatory variables. Their regression results indicated that fiscal decentralization is negatively correlated with growth in Central and Eastern Europe during the period of analysis. In addition, the regression results established that the coefficient of the transfers from national government to the sub-national government were negative but not statistically significant. Higher shares of transfers from other levels of government were found to be negatively correlated with economic growth implying that the higher the dependence on transfers from the national government, the lower the economic growth rate.

[3] explored the relationship between fiscal decentralization and economic growth in USA using time series data and found that fiscal decentralization was positive and statistically significant. They used the ratio of subnational revenue as a percentage of the national revenue to measure fiscal decentralization. [19] found that fiscal decentralization led to significant contribution to economic growth in China. They used an econometric model with growth rate per capita GDP as the regressand and the ratio of devolved finance as a percentage of the total government spending as the regressor. Fiscal decentralization was found to have a positive and significant relationship with growth rate per capita GDP. Their model suggested that fiscal decentralization should lead to 3.62 percent increase in per capita GDP.

[8] Observe that there is a significant negative relationship between fiscal decentralization and economic growth in developing countries and none in developed countries. They interpret the negative relationship to mean that excessive recurrent expenditure by local authorities and sub-national governments is unlikely to lead to higher growth.

[36] Found a negative relationship between fiscal decentralization and economic growth in China. They used a time series data for the period 1986 to 1992. The coefficient of fiscal decentralization was negative. This implied that an increase in sub-national government expenditure causes a decline in the growth rate. From these discussions therefore, it is clear that economic theory is inconsistent with empirical evidence concerning the relationship between fiscal decentralization and economic growth hence welfare as some studies reveal that fiscal decentralization leads to improved economic efficiency hence growth, which ultimately leads to improved welfare while some studies reveal the opposite. 
[1] Using ordinary least squares method analyzed the effects of fiscal decentralization on the growth of Nigerian economy from 1970 to 2009 and their results indicated that lower levels of government depend heavily on the federal government for revenue. As a result, they recommended a constitutional amendment to devolve some of the higher revenue yielding sources to the lower levels of government to improve their internal revenue base and for the government to strengthen measures for fighting corruption in public offices whose end result is unequal distribution of resources in society.

\section{Methodology}

\section{Conceptual Framework}

Fiscal funds are used to provide public goods and services from which members of society derive utility. Unlike private goods, public goods are non-rival in consumption and nonexcludable. It is assumed that people consume a public good denoted by $\mathrm{G}$ and a private good denoted by $\mathrm{C}$. Everyone consumes the same amount of public good $G$, so that the utility function can be written as

$$
\mathrm{U}_{\mathrm{i}}=U\left(G, C_{\mathrm{i}}\right)
$$

Where $\mathrm{i}=1,2 \ldots \mathrm{n}$

Although all the $n$ consume same amount of good G, each $\mathrm{n}$ values $\mathrm{G}$ differently.

Optimization Behavior

$$
\text { Maximize welfare, } \mathrm{W}=w(G, C)
$$

Subject to Fiscal funds $(\mathrm{Y})=P 1 G+P 2 C$

Where, $\mathrm{Y}$ is the budget constraint, which equals the sum of fiscal funds.

$P_{1}$ is the sum of willingness to pay for $G$

$\mathrm{P}_{2}$ is the price of $\mathrm{C}$

Solving the above maximization problem gives the optimal demand for the public goods $(\mathrm{G})$ which maximizes society's welfare.

$$
G=g(P 1, P 2, Y, \mu)
$$

\section{Optimality Condition}

Since all consumers benefit from $\mathrm{G}$, its price is equivalent to the sum of their marginal willingness to pay for the good. The marginal willingness to pay for good $\mathrm{G}$ is measured by the marginal rate of substitution of the private good $(\mathrm{C})$ for the public good $(\mathrm{G})$ which is the ratio of the marginal utilities computed from the underlying utility functions for each individual member of society.

$$
\mathrm{MRS}_{\mathrm{G}, \mathrm{C}}=-\frac{M U G}{M U C}
$$

Equation (4) above is negative but at equilibrium everyone's MRS is equal to $\mathrm{P}_{\mathrm{g}} / \mathrm{P}_{\mathrm{c}}$.

Total marginal willingness to pay is given by

$$
M R S_{\mathrm{G}, \mathrm{C}}^{1}+M R S_{\mathrm{G}, \mathrm{C}}^{2}+\ldots+M R S_{\mathrm{G}, \mathrm{C}}^{n}
$$

The optimal level of a public good is found at the point where the total marginal willingness to pay for the public good equals the marginal cost of providing the good [34]. This condition is given by the equation below:

$$
M R S_{\mathrm{G}, \mathrm{C}}+M R S_{\mathrm{G}, \mathrm{C}}^{2}+\ldots+M R S_{\mathrm{G}, \mathrm{C}}^{n}=\mathrm{MC}_{\mathrm{G}}
$$

$\mathrm{MC}_{\mathrm{G}}$ is the marginal cost of providing public the good so that the demand for $\mathrm{G}$ is a function of $\mathrm{MC}_{\mathrm{G}}$, ceteris paribus.

Data and Empirical Model

This study used free education in primary schools in Kenya as a public good. Education in public primary schools is free, thus considered a public good. The quantity of the public good $(\mathrm{G})$ is measured by annual enrollment in class one from 1970 to 2015. Time series data on government expenditure on education, enrollment in public primary schools, CDF allocations, parents' literacy levels and pupilteacher ratio was sourced from World Bank metadata, ADB development indicators, statistical abstracts and economic surveys.

The marginal cost of providing $\mathrm{G}$ is assumed to be equal to the annual expenditure by the government on primary education divided by the number of pupils admitted in standard one in public schools.

$$
G=g(M C g, \text { parent literacy, pupil - teacher ratio } \mu)
$$

The following Cobb-Douglas demand equation was estimated using OLS.

$$
\begin{gathered}
\ln G=B 0+B 1 M C g+B 2 C d f a+B 3 \ln P L+ \\
B 4 \ln \left(\frac{P}{T}\right) \text { ratio }+\mu
\end{gathered}
$$

where

$\mathrm{MC}_{\mathrm{g}}$-Marginal cost of providing education in public primary schools. It is given by government expenditure on primary education divided by the number of pupils admitted in standard/ grade one. It is the cost of providing education per pupil.

G- Is annual enrollment in public primary schools.

Cdf2 - Is a dummy variable showing whether in a particular year CDF had been introduced or not.

$\mathrm{P}$ and $\mathrm{T}$ are pupils and teachers, respectively.

\section{Empirical Results and Discussion}

\subsection{Descriptive Statistics}

The highest percentage of GDP per pupil ( $\mathrm{MCg}$ ) that the government has ever spent on primary education is $0.00128 \%$ while the minimum percentage is $0.000381 \%$. Enrollment in standard (grade) one has been increasing drastically since 1970 with the highest and lowest records being 1,541,506 and 296,459 pupils respectively. Average annual enrollment stands at 966,572 pupils. The average annual pupil-teacher ratio stands at 41.22865 implying that on average one teacher is supposed to serve about 42 pupils. The highest literacy level for the period under study stands at $78.124 \%$ while the lowest literacy level was $54.987 \%$. In the above table, cdf allocation is 
a dummy variable and takes the values 0 and 1 . The value zero refers to the period prior to introduction of CDF while the value 1 refers to the period when cdf was introduced and onwards. The table shows that of the 46 years considered in the study, there were 34 years (from 1970 to 2003) when cdf had not been introduced and 12 years (from 2004 to 2015) when cdf had already been introduced. The objective here is to compare and show whether the introduction of CDF has influenced demand for education in Kenya.
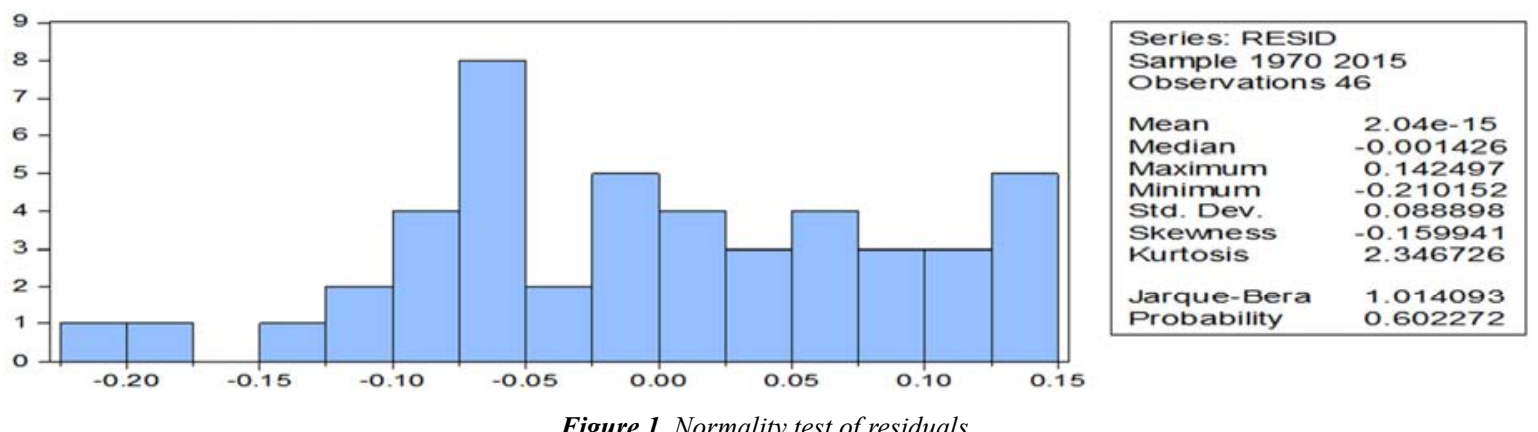

Figure 1. Normality test of residuals

Table 1. Descriptive statistics.

\begin{tabular}{llllll}
\hline Variable & Observations & Mean & Std. Dev. & Min & Max \\
\hline Enrolment & 46 & 966571.5 & 299843.5 & 296459 \\
Mcg*10000 & 46 & 0.0659 & 0.0223 & 0.0381 \\
Pupil-T ratio & 46 & 41.22865 & 23.92725 & 30.357 & 0.128 \\
Literacy level & 46 & 67.03274 & 5.59172 & 54.987 & 192.091 \\
Cdf2 (Cdf $=1)$ & 12 & 0.2608696 & .4439611 & 0 & 78.124 \\
Cdf1 (Cdf $=0)$ & 34 & 0.7391304 & .4439611 & 0 & 1 \\
\hline
\end{tabular}

\section{Test of normality}

The Shapiro-Wilk test was conducted and the results in the table below were obtained.

Table 2. Results for Shapiro-Wilk / Normality test results.

\begin{tabular}{llllll}
\hline Variable & Observations & $\mathbf{W}$ & $\mathbf{V}$ & $\mathbf{Z}$ & $\mathbf{P r o b}>\mathbf{z}$ \\
\hline Enrolment & 46 & 0.92491 & 3.308 & 2.539 & 0.00556 \\
Mcg (Expenditure) & 46 & 0.97817 & 0.961 & -0.083 & 0.53322 \\
Pupil-t ratio & 46 & 0.36773 & 27.853 & 7.060 & 0.00000 \\
Literacy level & 46 & 0.97745 & 0.993 & -0.014 & 0.50559 \\
\hline
\end{tabular}

The p-values for Mcg and literacy level are greater than 5\% while the $\mathrm{p}$-values for enrolment and pupil-teacher ratio are less than $5 \%$. Therefore, the data on Mcg and literacy level is normal while enrollment and pupil-teacher ratio is not normal. Since some variables failed the normality test, normality test for residuals was adopted and the plot as shown in figure 1 reveal absence of severe outliers.

The error term was tested for normality and the above results were obtained. It was found to be normally distributed as shown by the Jarque-Bera test ( $p$-value $=0.602272$ ).

The results in figure 2 show the trend analysis of $\log$ enrollment, $\mathrm{MCg}$, log parent literacy and $\log$ pupil-teacher ratio for the period 1970 to 2015 . The figures reveal that enrollment and level of parent literacy has been on the rise while marginal cost of providing education in primary school has been declining. Pupil teacher ratio was very high in 1990s showing that there were few teachers compared to pupils during this time. The trends of log enrollment and log parent literacy show that there could be a close association between the two.

Multi-collinearity test (Pearson correlation)

Table 3. Correlation matrix.

\begin{tabular}{llll}
\hline & Ln enrollment & MCg & Ln parent literacy \\
\hline Log enrollment & 1.0000 & & \\
MCg & -0.964624 & 1.0000 & 1.0000 \\
Log parent literacy & 0.863069 & -0.822549 & 0.373351 \\
Log p-teacher ratio & 0.352371 & -0.299393 & 1.0000 \\
\hline
\end{tabular}

Table 3 presents results of Pearson's bivariate correlation. The results indicate that enrollment and $\mathrm{MCg}$ have a negative correlation (-0.964624) but positively correlated with parent literacy (0.863069) and pupil teacher ratio (0.352371). $\mathrm{MCg}$ is negatively correlated with both parent literacy $(-0.822549)$ and pupil teacher ratio $(-0.299393)$. Parent literacy and pupilteacher ratio are positively correlated (0.373351).

Unit root test (test for stationarity)

The variables specified in the model were subjected to the test and the following results obtained.
Table 4. Augmented Dickey-Fuller Test Results.

\begin{tabular}{lllll}
\hline Variable & $\begin{array}{l}\text { Ln } \\
\text { enrollment }\end{array}$ & Mcg & $\begin{array}{l}\text { Ln parent } \\
\text { literacy }\end{array}$ & $\begin{array}{l}\text { Ln pupil-teacher } \\
\text { ratio }\end{array}$ \\
\hline $\begin{array}{l}\text { Order of } \\
\text { integration }\end{array}$ & $\mathrm{I}(1)$ & $\mathrm{I}(1)$ & $\mathrm{I}(1)$ & $\mathrm{I}(0)$ \\
\hline
\end{tabular}

From the ADF criterion, the variables Ln enrollment, $\mathrm{MCg}$ and Ln parent literacy were found to contain a unit root while Ln pupil-teacher ratio did not hence it was stationary at levels. 
The variables Ln enrollment, MCg and Ln parent literacy were differenced and became stationary after first differencing. They were found to be integrated of order 1 while Pupil-Teacher ratio was integrated of order 0.

Testing for heteroscedasticity

The study employed Park test to test for heteroscedasticity. The test found that $\mathrm{Ln} \mathrm{MCg}$ was the one causing heteroscedasticity with a P-value of 0.0000 and a t-statistic of -12.86 implying that variance of the error term varied over time. Using OLS in this case would lead to estimates no

logenrolment

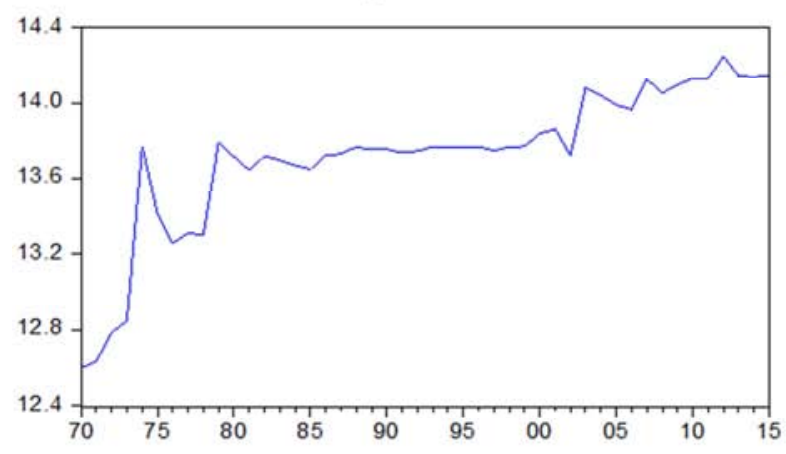

logparentliteracy

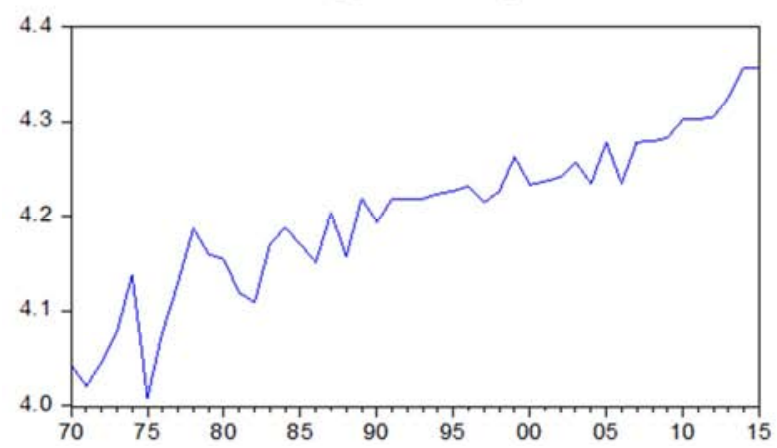

longer having minimum variance and as a result, the standard errors would be biased leading to adversely affected inference. To avoid this problem, the Newey West regression was adopted as a remedy. The estimates of Newey West regression are both unbiased and efficient. In addition, since some of the variables were not stationary at levels, differencing them would lead to loss of important statistical information about the variables. Newey West regression assisted to avoid this problem.
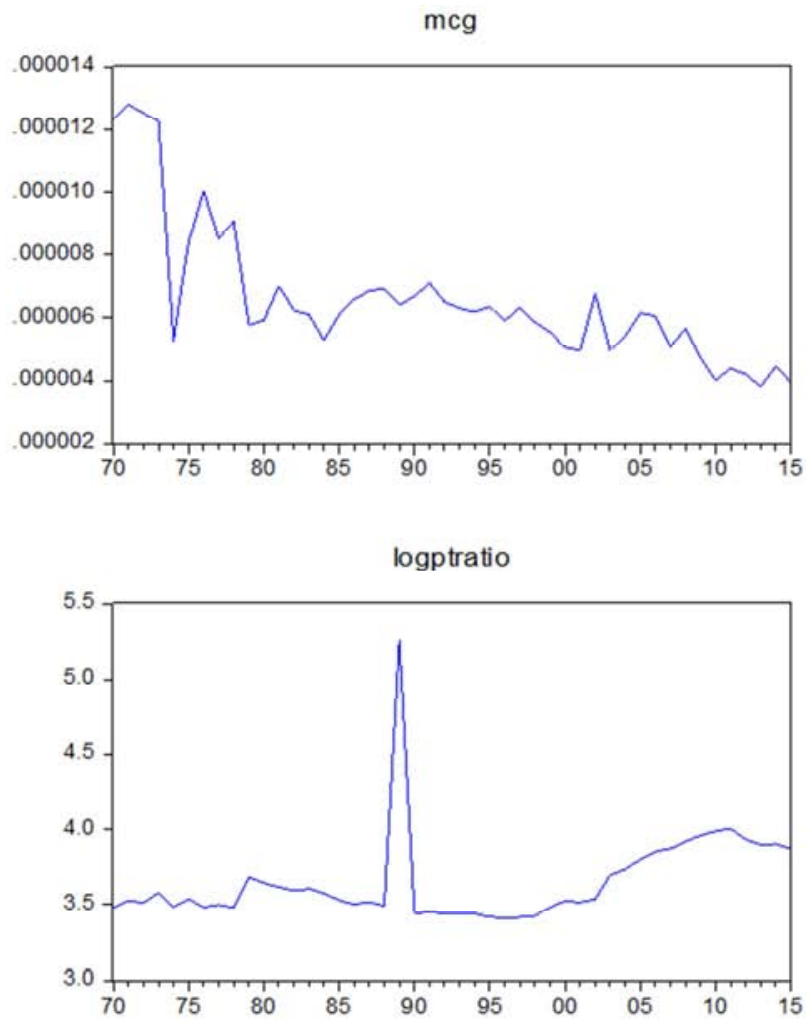

Figure 2. Trend analysis.

\subsection{Regression Results}

Table 5. Demand for primary education: dependent variable is annual enrollment.

\begin{tabular}{lll}
\hline Variables & Coefficient & $\boldsymbol{t}$-statistic \\
\hline Ln Mcg & $-1.031^{* * *}$ & -7.68 \\
Cdf2 & 0.0335 & 0.46 \\
Ln Parent Literacy & $0.0108^{*}$ & 1.82 \\
Ln (P-T) ratio & 0.000228 & 1.18 \\
Constant & 0.636 & 0.41 \\
\hline
\end{tabular}

The coefficient of determination or R-squared is $90.8 \%$ implying that the independent variables in question ( $\mathrm{Ln} \mathrm{Mcg}$, Cdf2, Ln Parent Literacy and Ln (P-T) ration) explain up to $90.8 \%$ of the variations in the level of annual enrollment. The F-statistic of 34.71 and a P-value equal to 0.000 indicate that the model is a good fit.

The coefficient on $\mathrm{Ln} \mathrm{MCg}$ is negative and statistically different from zero. The results imply that a $1 \%$ increase in $\mathrm{MCg}$ reduces primary enrollment by $1.03 \%$. This is so because as public primary education is made free, some parents (those who are well off in society) tend to think that the quality of public education has been compromised and transfer their children to private schools where they believe the quality of education is better irrespective of the huge fees they pay. In fact, the large amounts of fees paid in private schools is what makes people think the quality of education offered in private schools is better than in public schools. In addition, when primary education is made free, it is user fee that is abolished but taxes are being paid and in fact, the rate of taxation increases. The coefficient on cdf 2 is positive and statistically significant. The revelation here is that the years when cdf was in place recorded a large increase in enrollment relative to the years without cdf.

The coefficient on Ln Parent literacy is positive and statistically different from zero. In particular, a percentage increase in parents' education is associated with $0.0108 \%$ increase in enrollment. The Pupil-Teacher ratio has a positive effect on enrollment though its coefficient is not statistically different from zero. 


\section{Conclusion}

The study was designed to determine the effect of fiscal funds on social welfare. The effect of CDF (Constituency Development Fund) on the demand for primary education, which is a quasi-public good [7], was analyzed. The study revealed that CDF has had a significant impact on primary schooling. The introduction of CDF in 2004 increased enrollment in public schools considerably. The fund made it easy for schools to build more classes, toilets, libraries and other learning facilities. In addition, through the fund, many schools were built in places where they never existed before. This reduced the long distances that pupils used to walk to schools. Therefore, the government should consider increasing CDF allocations as it has been shown to trigger demand for primary schooling.

The results further show that MCg (a proxy for government expenditure per primary school pupil) is negatively associated with enrollment. The government expenditure on pupils in public schools was a move meant to reduce the user fees in schools and encourage more people to have access to basic education. However, from the results, it implies that in order to increase enrollment, the government has to reduce $\mathrm{MCg}$ (expenditure per pupil). This contradicts the objective for introducing the fund. This finding conforms to the findings of [6], which showed that the abolition of user fee for government primary schools in Kenya in 2003 did not significantly increase net enrollment in public schools. The evidence on Pupil-Teacher ratio suggests that there are no enrollment gains to be had by existing staffing norms in primary schools.

To increase efficiency of the constituency development fund, that is, to make sure that the fund actually does what it was intended to do, the government needs to train or equip school heads with necessary managerial skills which are key to implementation of the fund. This is evident in [16]; there is a significant relationship between managerial factors, and social factors and implementation of CDF projects. This will boost the quality of schooling in Kenya.

\section{References}

[1] Abachi, P. T., \& Salamatu, I. (2012). An analysis of the effect of fiscal decentralization on economic growth in Nigeria. International Journal of Humanities and Social Science Vol. 2 No, 8 .

[2] Ahuja, H. L. (2009). Modern microeconomics: Theory and applications. New Delhi: S. Chand.

[3] Akai, N., \& Sakata, M. (2002). Fiscal decentralization contributes to economic growth: evidence from state-level cross-section data for the United States. Journal of urban economics, 52 (1), 93-108.

[4] Amagoh, F., \& Amin, A. A. (2012). An examination of the impacts of fiscal decentralization on economic growth. International Journal of Business Administration, 3 (6), 72.

[5] Bagaka, O. (2008). Fiscal decentralization in Kenya: The constituency development fund and the growth of government.
[6] Bold, T., Kimenyi, M., Mwabu, G., \& Sandefur, J. (2011). Why did abolishing fees not increase public school enrollment in Kenya?

[7] Chaudhary, L., Musacchio, A., Nafziger, S., \& Yan, S. (2012). Big BRICs, weak foundations: The beginning of public elementary education in Brazil, Russia, India, and China. Explorations in Economic History, 49 (2), 221-240.

[8] Davoodi, H., \& Zou, H. F. (1998). Fiscal decentralization and economic growth: A cross-country study. Journal of Urban economics, 43 (2), 244-257.

[9] Ebel, R. D., \& Yilmaz, S. (2002). On the measurement and impact of fiscal decentralization (Vol. 2809). World Bank Publications.

[10] Gakuru, R., \& Mathenge, N. (2011). Poverty, growth, and income inequality in Kenya: A SAM perspective. Nairobi, Kenya: Kenya Institute for Public Policy Research and Analysis.

[11] ICPAK. (September 2014). Position paper on the impact of decentralized funds in Kenya. Institute of Certified Public Accountants of Kenya.

[12] Kenya National Bureau of Statistics, (2010). The 2009 Kenya population and housing census. Nairobi: Kenya National Bureau of Statistics.

[13] Kenya. (1999). National Poverty Eradication Plan 1999-2015. Nairobi, Government of Kenya.

[14] Kenya. (2007). Kenya vision 2030. Nairobi, Kenya: Government of Kenya.

[15] Kenya, \& Kenya. (2008). First medium term plan, 2008-2012: Kenya vision 2030: a globally competitive and prosperous Kenya. Nairobi: Office of the Prime Minister, Ministry of State for Planning, National Development, and Vision 2030.

[16] Kibebe, L. W., \& Mwirigi, P. W. (2014). Selected Factors Influencing Effective Implementation of Constituency Development Fund (CDF) Projects in Kimilili Constituency, Bungoma County, Kenya. International Journal of Science and Research, 3 (1), 44-48.

[17] KIPPRA (2009): Baseline Survey on Decentralized Funds in Kenya, Kenya Institute for Public Policy, Research and Analysis (KIPPRA), Nairobi, Kenya.

[18] KNBS. (2007). Kenya Integrated Household Budget Survey (2005/2006). Nairobi: Government Printer.

[19] Lin, J. Y., \& Liu, Z. (2000). Fiscal decentralization and economic growth in China. Economic development and cultural change, 49 (1), 1-21.

[20] Morgan, K. (2006). Devolution and development: Territorial justice and the North-South divide. Publius: The Journal of Federalism, 36 (1), 189-206.

[21] Munga, B., \& Wambugu, A. (2009). Growth, Poverty and Inequality in Kenya: Suggested Policy Options. KIPPRA/NESC/UNDP Royal danish Embassy Project.

[22] Muriu, A. R. (2013). Decentralization, citizen participation and local public service delivery: A study on the nature and influence of citizen participation on decentralized service delivery in Kenya (Master's thesis, Potsdam: Universitätsverlag Potsdam). 
[23] Musgrave, R. A. (1959). Theory of public finance; a study in public economy.

[24] Mwenda, A. K., \& Institute of Economic Affairs (Kenya). (2010). Devolution in Kenya: Prospects, challenges and the future. Nairobi, Kenya: Institute of Economic Affairs.

[25] Nyangena, W., Misati, G. N., \& Naburi, D. N. (2010). How Are Our Monies Spent? The Public Expenditure Review in Eight Constituencies (2005/2006-2008/2009). Nairobi: ActionAid International Kenya.

[26] Persson, T., \& Tabellini, G. (1994). Is inequality harmful for growth? The American Economic Review, 600-621.

[27] Prud'homme, R. (January 01, 1995). The Dangers of Decentralization. The World Bank Research Observer, 10 (2), 201-220.

[28] Republic of Kenya (various issues). Economic Survey, Kenya National Bureau of Statistics. Government printer, Nairobi.

[29] Republic of Kenya (various issues). Leading Economic Indicators, Kenya National bureau of Statistics. Government printer, Nairobi.

[30] Republic of Kenya (various issues). Statistical Abstracts, Kenya National Bureau of Statistics. Government printer, Nairobi.
[31] Rodden, J. (2002). The dilemma of fiscal federalism: Grants and fiscal performance around the world. American Journal of Political Science, 670-687.

[32] Rodríguez-Pose, A. N. D. R. É. S., \& Krøijer, A. (2009). Fiscal decentralization and economic growth in Central and Eastern Europe. Growth and Change, 40 (3), 387-417.

[33] Rodríguez-Pose, A., \& Ezcurra, R. (2010). Is fiscal decentralization harmful for economic growth? Evidence from the OECD countries. Journal of Economic Geography, 11 (4), 619-643.

[34] Samuelson, P. A. (1954). The pure theory of public expenditure. The review of economics and statistics, 36 (4), 387-389.

[35] Tanzi, V. (1995). Fiscal federalism and decentralization: A review of some efficiency and macro-economic aspects, paper prepared for the World Bank's annual bank conference on development economics. Washington, DC.

[36] Zhang, T., \& Zou, H. F. (1998). Fiscal decentralization, public spending, and economic growth in China. Journal of public economics, 67 (2), 221-240. 